Seuran tuotot koostuivat pääosin jäsenmaksuista, jotka olivat 4035,75 euroa. Seuran varsinaisen toiminnan kulut olivat 3895,84 euroa, ja ne koostuivat pääosin taloushallinnon palveluista (1 016,34 euroa), jäsenkokousten järjestämisestä, rahaliikenteen kuluista sekä jäsen- ja viranomaismaksuista. Sijoitusja rahoitustoiminnan tulos oli 12750,17 euroa, ja rahastoihin tuotoista siirrettiin 12 550,17 euroa. Seuran tulos vuodelta 2019 on 184,51 euroa ylijäämäinen.
Kotikielen Seuran ja Virittäjän vuoden 2019 yhteinen tilinpäätös osoittaa tuottoja 70 111,66 euroa ja kuluja 57 873,67 euroa, ja rahastoille siirrettiin 12550,17 euroa. Alijäämäksi muodostuu 312,18 euroa.

Helsingissä 13. maaliskuuta 2020

Henri Satokangas Kotikielen Seuran sihteeri seura@kotikielenseura.fi

\title{
Etymologia ja epäsäännöllisyyden haasteet
}

Jeongdo Kim: Hulisemisesta hulinaksi. Onomatopoieettisuuden haalistuminen suomen fonesteemisten substantiivien valossa. Helsinki: Helsingin yliopisto 2019. 266 s. ISBN 978-951-51-5432-3. Saatavilla verkossa osoitteessa http://urn.fi/ URN:ISBN:ISBN 978-951-51-5433-0.

Jeongdo Kimin väitöskirjan aiheena on fonesteemiset substantiivit eli substantiivit, jotka voidaan äänneasunsa perusteella yhdistää onomatopoeettisiin verbeihin mutta joita ei voi pitää suoraan ääntä kuvailevina. Lähtökohta on, että fonesteemiset substantiivit ovat kehittyneet onomatopoeettisista verbeistä ja että tämä voidaan osoittaa johtosuhteiden ja merkityksenmuutosten tarkastelun avulla. Kirjoittaja nimittää muutosta onomatopoeettisuuden haalistumiseksi.

Onomatopoeettis-deskriptiivistä sanastoa on tutkittu paljon. Sanastossa on todettu olevan runsaasti sekä äänneasun että merkityksen epäsäännöllistä vaihtelua, jonka takia eri sanojen välisten yhteyksien kuvaus ja sanojen etymologiointi on osoittautunut vaikeaksi. Työn aihetta voi siis pitää merkittävänä niin sanaston kuvauksen kuin etymologisen tutkimuksen metodien kehittämisen kannalta.

\section{Aineiston rajaus}

Tutkimustehtävä on rajattu kuuden eri merkityskentän sanastoon. Merkityskentiksi on valittu 'elämöinti' (esim. hulina, humu, hilu), 'yhteenotto' (esim. jupakka, kahina, rytäkkä), 'tyhjä puhe' (esim. loru, juoru, huhu), 'viinaryyppy' (esim. napsu, paukku, tärsky), 'vetinen aine' (esim. litku, liru, hulina) ja 'hyrrä' (esim. hyrrä, vyrrä, pärrä). Kenttien valintaan ovat tekijän mukaan vaikuttaneet lähinnä käytännön syyt: niistä löytyy tarpeeksi sanoja, joita on pidetty fonesteemisina ja joille löytyy riittävästi rinnakkaistapauksia. Tästä seuraa, että merkityskenttien välillä ei ole mitään semanttista 
tai äänteellistä yhteyttä. Ne eroavat toisistaan myös siinä, miten lähellä ne ovat onomatopoeettista merkitystä: 'tyhjän puheen' ja 'elämöinnin' yhteys onomatopoeettiseen sanastoon on ilmeinen, mutta 'hyrrä' tai 'vetinen aine' ovat korkeintaan äänen aiheuttajia.

Rajausta ei siis voi pitää aineiston yhtenäisyyden kannalta kovin onnistuneena, vaikka käytännölliseltä kannalta se onkin perusteltu. Lisäksi kun termi fonesteeminen viittaa yhtä lailla äänneasuun kuin merkitykseenkin, herää kysymys, olisiko rajauksen voinut tehdä myös äänteellisin perustein keskittymällä esimerkiksi tiettyjä fonesteemeja sisältäviin sanoihin. Toisaalta merkitykseen keskittymistä voi pitää työn vahvuutena, koska aiemmassa tutkimuksessa merkityssuhteita ei ole useinkaan käsitelty riittävästi.

\section{Tutkimustehtävä}

Tutkimuksen kolme keskeistä tarkastelunkohdetta ovat onomatopoeettisesti haalistuneiden sanojen johtosuhteet ja semanttinen kehitys, alkuperäisen äänen merkityksen leksikaalistuminen sekä haalistumiseen johtaneiden merkityksenkehitysten universaalius (s. 4). Työn rakenne etenee tuttuun tapaan: Ensimmäisesssä luvussa esitellään tutkimusaihe ja tutkimuksen tavoite ja toisessa luvussa keskeiset käsitteet, kuten onomatopoeettisuus, deskriptiivisyys ja fonesteemi. Kolmas luku tarjoaa katsauksen onomatopoeettis-deskriptiivisten sanojen tutkimushistoriaan, etenkin suomen kielen näkökulmasta. Neljäs luku on omistettu aineistonkäsittelylle, joka etenee merkityskenttien mukaan, ja tutkimustulokset kootaan yhteen viidennessä luvussa.

Tämän tutkimuksen aineistossa, kuten onomatopoeettis-deskriptiivisessä sanastossa yleensäkään, johtosuhteet eivät ole useinkaan puhtaan suffiksaalisia, ja siksi niiden kuvaamiseen tarvitaan korrelaatiojohdon, vartalojohdon ja takaperoisjoh- don käsitteitä. Esimerkkejä korrelaatiosuhteista ovat hulina ja hulista (s. 68), jupakka ja jupista (s. 108) ja naukku ja naukata (s. 137). Vartalojohdosta on taas kyse esimerkiksi vartalonpidennyksessä, joka näkyy verbeissä puuhata, touhuta ja juoruta (vrt. puhata, tohuta ja joruta, s. 200), ja takaperoisjohdoksia ovat sellaiset tapaukset kuin humu (< humuta, s. 70), puuha (< puuhata, s. 77) ja juoru (< juoruta, s. 115).

Mieleen nousee kuitenkin kysymys, voisiko fonesteemisten substantiivien muodostusta käsitellä holistisesti sanahahmon tai muotin käsitteiden avulla samaan tapaan kuin Iso suomen kielioppi (VISK 2004, esim. \$148) tai Koivisto (2013). Esimerkiksi sivulla 157 todetaan, että "litku ja latku ovat johdoksia verbeistä litkiä ja latkia, kun taas letku ja lutku ovat ensi vokaalin vaihtelun eli vartalojohdon kautta muodostettuja”. Ilmeisesti tämä ratkaisu johtuu siitä, että kirjoittajan mielestä vain johtosuhteet ovat diakronisia eikä sanahahmon käsitettä tulisi käyttää sanojen etymologioinnissa. Kirjoittaja kuitenkin tukeutuu perussanamuotin käsitteeseen selittäessään joitakin hyrrän nimityksiä, kun muita apuneuvoja ei enää ole (s. 194-195, 200).

Leksikaalistuminen määritellään työssä jatkumoksi tai kehityskuluksi, jonka aluksi sanan merkitys on ollut kompositionaalinen eli osien merkityksistä johdettava (s. 52). Tutkimuskysymyksen kannalta on olennaista, että tämä alkuperäinen merkitys on ollut onomatopoeettinen, eli tarkasteltavilla substantiiveilla on tai on ollut konkreettisen äänen merkitys. Niinpä esimerkiksi viinaryypyn nimitykset paukku ja tärsky pohjautuvat metaforisesti iskemisestä aiheutuvaan ääneen (s. 133), ja huonon juoman nimitys liru on leksikaalistunut "lirisevän äänen" merkityksestä (s. 159).

Etymologian periaatteiden mukaan oletettu merkityksenkehitys, tässä tapauksessa siis onomatopoeettisuuden haalistu- 
minen, pitää pystyä perustelemaan ainakin rinnakkaistapausten avulla. Kirjoittaja ei kuitenkaan tyydy tähän, vaan esittää ajatuksen merkityksenkehitysten universaaleista tendensseistä, jotka voidaan erottaa esimerkiksi analogian, sukukielten välisen yhteisen sanaston tai merkityslainojen aiheuttamasta merkityksenkehityksestä. Näitä tendenssejä tukemaan hän etsii semanttisia paralleeleja sekä sanakirjoista että semanttisista tietokannoista. Tätä voi pitää hyvin laajana tutkimustehtävänä, ja kirjoittaja onkin ilmeisen tietoinen siitä, että siihen on mahdotonta löytää tyhjentävää vastausta yhden monografian rajoissa.

\section{Terminologia ja teorian hallinta}

Työn keskeiset käsitteet, kuten onomatopoieettisuus, deskriptiivisyys ja fonesteemi, määritellään selkeästi. Tätä voi pitää ansiokkaana, sillä aiemmissa tutkimuksissa näiden termien käyttö on ollut kirjavaa. Kirjoittaja käyttää termiä onomatopoieettisuuden haalistuminen tutumman neutraalistumisen sijaan, mikä on hyvin perusteltu (s. 1-2). Fonesteemin käsitteen käytössä on horjuvuutta sen suhteen, voidaanko sitä pitää johtoopin termein kantana tai kantavartalona. Kirjoittaja käyttää kyllä esimerkiksi sanaa fonesteemikantainen (s. 38, 41) ja toteaa onomatopoeettisten sanojen olevan johdoksia, "jotka koostuvat fonesteemeista ja johtimista" (s. 52), mutta toisaalta määrittelee fonesteemin "sananalkuiseksi sananmuodostuselementiksi" (s. 27).

Kirjoittaja tuntee suomen kielen onomatopoeettis-deskriptiivistä sanastoa käsittelevän etymologisen tutkimuksen hyvin ja ottaa huomioon myös muita kieliä käsittelevän kirjallisuuden, vaikka joitakin lähteitä on käytetty niukanlaisesti (esim Marttila 2010; Voeltz \& Kilian-Hatz toim. 2001). Etymologisen tutkimuksen näkökulmasta lisiä olisivat voineet tarjota myös Malkiel (1993) tai Durkin (2009).
Työssä käsiteltyihin merkityskenttiin liittyy runsaasti äänteellisesti ja semanttisesti läheisiä sanoja, jotka muodostavat laajoja sikermiä. Niiden historiaa, levikkiä ja merkityksenkehitystä selvittäessään tutkimus laajenee suomen lähisukukieliin ja semanttisten paralleelien osalta muihinkin kieliin.

Sukukielten esimerkkejä on etsitty lähinnä karjalan ja viron kielen sanakirjoista. Sukukielestä olisi kuitenkin ollut käytettävissä enemmänkin lähteitä (esim. virosta EMS; karjalasta Karjalan varšinaismurtehien šanakirja 2009; vepsästä Zaitseva \& Mullonen 1972). Niinpä on syytä suhtautua varauksella tapauksiin, joissa kirjoittaja ei löydä lähisukukielten vastineista äänen merkitystä tai semanttisia paralleeleja. Sitä voi myös epäillä, miten kattavasti eri fonesteemien levikki itämerensuomalaisisa kielissä on esitetty. Sukukielten aineisto jää hajanaiseksi, eikä sitä voi käyttää etenkään negatiivisiin johtopäätöksiin, joiden kanssa etymologin toki on muutenkin oltava hyvin varovainen.

\section{Tutkimustulokset}

Tutkimuksen tärkein panos on se, että se pystyy vakuuttavasti yhdistämään eri merkityskenttien fonesteemiset substantiivit onomatopoeettisiin verbeihin, toisin sanoen osoittamaan otsikon mukaisesti "onomatopoieettisuuden haalistumisen". Havainnot eivät jää yksittäisiksi, vaan ne saavat tukea useista eri merkitysryhmistä. Perinteinen johto-opin käsitteistö ei sovi käsiteltävään sanastoon kovin hyvin, mutta kirjoittaja käyttää kuitenkin korrelaatiojohdon, vartalojohdon ja takaperoisjohdon käsitteitä systemaattisesti ja pystyy niiden avulla valaisemaan sanojen välisiä suhteita.

Leksikaalistumisesta todetaan, että se korreloi substantiivityyppien produktiivisuuden kanssa. Tätä ei voi pitää kovinkaan yllättävänä, koska leksikaalistumisen 
edellytyksenä on jo määritelmällisesti, että substantiivilla on alun perin ollut äänen merkitys. Se on taas helpointa osoittaa silloin, kun johtosuhde on säännöllinen eli produktiivinen. Suoranaisesta kehäpäätelmästä ei kuitenkaan voi puhua, koska kirjoittaja voi osoittaa tai ainakin olettaa leksikaalistumista tapahtuneen muulloinkin kuin täysin produktiivisissa johdoksissa.

Tutkimuksen tehtävistä ensimmäisen ja toisen voi siis katsoa toteutuneen. Kolmas, semanttisten paralleelien osoittaminen, ei onnistu aivan yhtä hyvin, mikä näkyy myös kovin varovaisissa johtopäätöksissä (s. 204). Muiden kielten semanttisia paralleeleja on etsitty kahdesta tietokannasta, jotka valitettavasti eivät loppujen lopuksi osoittaudu kovinkaan hyödyllisiksi. Tietokantoja kuitenkin täydennetään muilla lähteillä. Universaalien merkityksenkehitysten todentaminen vaatisi erittäin laajaa aineistoa, joten on luonnollista, että se jää nyt kesken. "Semanttisen polygeneesin" (s. 6o) hahmottelua pitäisin enemmänkin mielenkiintoisena keskustelunavauksena kuin varsinaisena tutkimustuloksena. Tutkimustulosten tarkastelu Saarikiven (2016) sanaryhmäluokittelun mukaan (s. 206-207) jää irralliseksi, ja se saa liikaa painoarvoa, kun kyseessä on kuitenkin hahmotelma, joka ei ole herättänyt laajempaa keskustelua eikä liity mitenkään erityisesti juuri tämän tutkimuksen kohteena olevaan sanastoon.

Kirjoittaja suhtautuu tuloksiinsa terveen kriittisesti ja ymmärtää aineistonsa epäsäännöllisyyden ja sen aiheuttamat haasteet. On helppo yhtyä hänen toteamukseensa (s. 201), että tämä "ei kuitenkaan tarkoita sitä, että onomatoeettisdeskriptiivisten [sic] sanojen kehitys on niin epäsäännöllistä, että sen tarkastelulla ei olisi mitään tieteellistä merkitystä”. Päinvastoin: juuri tämä epäsäännöllisyys on kiehtova haaste lahjakkaalle tutkijalle.

Jeongdo Kim toteaa lopuksi, että hänen seuraava tutkimushankkeensa on suomen onomatopoieettis-deskriptiivisen sanaston etymologisen sanakirjan laatiminen, ja hän antaa esimerkin sanaartikkelista $h u h u$. Kimille voi vain toivottaa onnea ja menestystä tässä kunnianhimoisessa hankkeessa, jonka tuloksia jäämme mielenkiinnolla odottamaan.

\section{VESA JARVA \\ etunimi.sukunimi@jyu.fi}

Kirjoittaja on suomen kielen yliopistonlehtori Jyväskylän yliopistossa ja toimi Jeongdo Kimin vastaväittäjänä.

\section{Lähteet}

Durkin, Philip 2009: The Oxford guide to etymology. Oxford: Oxford University Press.

EMS $=$ Eesti murrete sõnaraamat. $1-30$. Toimittaneet Tiiu Erelt \& Ülle Viks. Tallinn: Teaduste Akadeemia, Eesti Keele Instituut 1994-2019. http://www.eki.ee/ dict/ems/pdf.html (22.2.2020).

Karjalan varsinaismurtehien sanakirja 2009 = Словарь собственно-карельских говоров Карелии. Федотова В.П., Бойко Т.П. Словарь собственнокарельских говоров Карелии. Петрозаводск: Учреждение Российской акаде-мии наук, Инситут языка, литературы и истории Карельского научного центра РАН 2009.

KoIvisto, VESA 2013: Suomen sanojen rakenne. Helsinki: Suomalaisen Kirjallisuuden Seura.

Malkiel, Yakov 1993: Etymology. Cambridge: Cambridge University Press.

Marttila, Annu 2010: A cross-linguistic study of lexical iconicity and its manifestation in bird names. Doctoral dissertation. Helsinki: Unigrafia.

SAARIKIVI, JANNE 2016: Pieni essee sanojen kohtaloista. - О. П. Илюха (toim.), Финно-угорская мозаика: сборник статей к юбилею Ирмы Ивановны Муллонен s. 68-79. Studia Nordica I. Петрозаводск: Карельский научный 
центр РАН.

VISK = Hakulinen, AUli - Vilkuna,

Maria - Korhonen, Rittta -Koi-

visto, Vesa - Heinonen, Tarja

RiIt ta - Alho, IrJa 2004: Iso suomen

kielioppi. Helsinki: Suomalaisen Kirjal-

lisuuden Seura. Verkkoversio. http:// scripta.kotus.fi/visk (22.2.2020).

Voeltz, F. K. Erhard - Kilian-Hatz, Christa (toim.) 2001: Ideophones.

Amsterdam: Benjamins.

Zaitseva, M. I - Mullonen, M. I. 1972:

Slovarj vepsskogo jazyka. Leningrad:

Nauka.

\section{Monipuolinen esitys (lähes) tuntemattomasta maanlainsuomennoksesta}

\author{
Harri Uusitalo: Tausta, tekijä ja kieli. \\ Filologinen tutkimus Aitolahden koodeksin \\ lainsuomennoksesta. Turun yliopiston \\ julkaisuja C471. Turku 2019. 159 s. ja liit- \\ teet 186 s. ISBN 978-951-29-7668-3. Saata- \\ villa verkossa osoitteessa http://urn.fi/ \\ URN:ISBN:978-951-29-7669-0.
}

Harri Uusitalon väitöskirja käsittelee Aitolahden koodeksiin sisältyvää kuningas Kristofferin maanlain suomennosta. Itse koodeksi löydettiin vuonna 1922 navetan vintiltä ja toimitettiin vuonna 1963 Suomalaisen Kirjallisuuden Seuralle. Koodeksiin sisältyy lainsuomennoksen ohessa erilaisia lyhyempiä ruotsinkielisiä tekstejä, muun muassa Lentuluksen kirjeen ruotsinnos. Koodeksin tekstit edustavat eri käsialoja, mutta valtaosa suomen- ja ruotsinkielisestä tekstistä on kirjoitettu samalla käsialalla. Koodeksin maanlainsuomennoksella on selviä yhtäläisyyksiä sekä Martinus Olavin maanlainsuomennoksen (n. 1580) että Ljungo Thomaen maanlainsuomennoksen (1602) kanssa, mutta se ei ole suora kopio kummastakaan niistä. Martinus Olavin ensimmäisestä maanlainsuomennoksesta on säilynyt seitsemän kopiota, mutta Ljungon suomennoksesta vain yksi. Aitolahden lainsuomennos on tähänastisessa tutkimuksessa jäänyt melkein huomiotta, lukuun ottamatta Rapolan (1965) havaintoja. Uusitalon väitös- kirja on näin ollen ensimmäinen laaja tutkimus kyseisestä tekstistä. Tutkimus kohdistuu kielellisten yksityiskohtien asemesta tekstin taustaan kokonaisuudessaan: sen ikään, tekijään sekä suhteeseen muihin teksteihin, esimerkiksi Martinuksen ja Ljungon suomennoksiin.

Väitöskirjan varsinainen tutkimusosa on ytimekäs - 159 sivua lähdeviittaukset mukaan lukien. Lisäksi teokseen sisältyy liitteenä Aitolahden maanlainsuomennoksen kokonaisteksti. Johdantoluvussa Uusitalo esittelee tutkittavan koodeksin ohella lyhyesti vanhan kirjasuomen lakikielten tutkimushistoriaa, kehitysvaiheita ja tärkeimpiä merkkihenkilöitä. Lisäksi johdantoon sisältyy työn monipuolisen metodologian esittely; työssä hyödynnetään niin kodikologista tutkimusta, forensista lingvistiikkaa kuin käännöstutkimusta. Toisessa luvussa Uusitalo esittelee tutkimustavoitteensa: 1) Aitolahden koodeksin ajoitus kodikologian ja materiaalisen filologian menetelmin, 2) koodeksin intertekstuaalisuuden selvittäminen suhteessa Martinuksen ja Ljungon teksteihin, 3) tekijäntunnistus erityisesti suhteessa Rapolaan (1965), jonka mukaan tekijä olisi Hartvig Speitz, ja 4) koodeksin kielen vertailu vuoden 1642 Biblian kieleen. Näitä aiheita käsitellään luvuissa 3-6. Lopussa on hyvin lyhyt (kahden sivun) yhteenvetoluku. 